\title{
Gambaran Subjective Well-Being Dosen Dan Tenaga Pendidik
}

\author{
Anak Agung Sagung Suari Dewi \\ Universitas Bali Internasional \\ email: suaridewi@iikmpbali.ac.id
}

\begin{abstract}
Being a lecturer and educational staffs are a noble task because they aimed to build a greater young generation for the nation, so that their welfare should be well-attended. Wellbeing or is divided into two types, which are objective well-being (OWB) and subjective wellbeing (SWB). This is a descriptive survey research and focused more on SWB. The respondent criteria were lecturer and educational staff at the EB and $\mathrm{P}$ faculty, thus obtaining 74 respondents. The scale used in this study is SWB scale adapted from the Subjective Well-Being Inventory (SUBI) (Nagpal \& Sell, 1992), using an interval scale, and presented in statements. Examining the results, it can be seen that more than half $(71.62 \%)$ of the respondents considered that their life had been positive, both physically and mentally, which was indicated by a high SWB level. As many as 20 respondents $(27.03 \%)$ were at moderate level, and only $1.35 \%$ or 1 respondent had a low SWB level. Perceived ill-health dimension is the most contributor to the low level of SWB, which related to physical complaints experienced by individuals, such as pain, a racing heart, frequent dizziness, easily tired, sleep disturbed, and worrying about their health.
\end{abstract}

Keywords: subjective well-being, lecturer, educational staff.

Abstrak. Peran sebagai dosen dan tenaga kependidikan merupakan tugas yang mulia karena memiliki tujuan untuk membangun generasi muda bangsa yang lebih bermanfaat, sehingga sudah seharusnya dosen dan tenaga kependidikan diperhatikan kesejahteraannya. Kesejahteraan atau yang dalam Bahasa Inggris disebut dengan well-being terbagi menjadi 2 bentuk, yaitu subjective well-being (SWB) dan objective well-being (OWB). Penilitian ini akan lebih berfokus pada SWB. Penelitian ini berjenis survei deskriptif. Kriteria subjek penelitian adalah dosen dan tenaga kependidikan di fakultas EB dan P, sehingga memperoleh 74 responden. Penelitian ini menggunakan skala pengukuran subjective well-being (SWB) yang diadaptasi dari Subjective well-being inventory (SUBI) (Nagpal \& Sell, 1992). Jenis datanya adalah interval, dan tersaji dalam pernyataan. Menelaah hasil penelitian, terlihat bahwa lebih dari setengah $(71,62 \%)$ presentase responden menilai bahwa kehidupan mereka telah berjalan positif, baik secara fisik maupun mental, yang dinyatakan dengan tingkat SWB tinggi. Sebanyak 20 responden $(27,03 \%)$ berada di tingkatan sedang, dan hanya 1,35\% atau 1 responden sisanya memiliki tingkat SWB rendah. Dimensi perceived ill-health paling berkontribusi dalam rendahnya tingkat SWB, yang terkait dengan keluhan fisik yang dialami individu, seperti sakit pada bagian tubuh, jantung berdebar kencang, sering merasa pening, mudah lelah, tidur terganggu, dan khawatir akan kesehatan.

Kata kunci: subjective well-being, dosen, tenaga kependidikan.

\section{Pendahuluan}

Dosen merupakan seorang pendidik dan ilmuwan yang memiliki tugas utama untuk mentransformasikan, mengembangkan, dan menyebarluaskan ilmu pengetahuan dan teknologi melalui pendidikan, penelitian, dan pengabdian kepada masyarakat (UU No. 12 tahun 2012), 
sedangkan tenaga kependidikan adalah masyarakat yang mengabdikan diri dan diangkat untuk menunjang penyelenggaraan pendidikan, seperti pustakawan, tenaga administrasi, laboran dan teknisi, serta pranata teknik informasi (Perpres No. 10 tahun 2016). Dosen memiliki beberapa tugas dan peran, diantaranya mentransformasikan ilmu pengetahuan dan/atau teknologi yang dikuasai kepada mahasiswa, sehingga mahasiswa aktif mengembangkan potensinya; sebagai ilmuwan untuk mengembangkan ilmu pengetahuan dan/atau teknologi yang dikuasai melalui penelitian dan penalaran ilmiah, serta menyebarluaskannya; dan wajib menulis buku ajar atau buku teks, yang diterbitkan oleh perguruan tinggi, sebagai sumber belajar dan untuk pembudayaan kegiatan baca tulis bagi sivitas akademika (UU No. 12 tahun 2012).

Dalam memperlancar tugas-tugas kependidikan yang dijalani dosen dan mahasiswa di sebuah universitas, tentu diperlukan tenaga yang mampu melaksanakan pengelolaan, administrasi, pengawasan, pengembangan, dan pelayanan teknis, yang disebut sebagai tenaga kependidikan. Jika dilihat dari jabatannya, tenaga kependidikan dapat dibedakan menjadi tiga jenis, yaitu tenaga fungsional, tenaga struktural, dan tenaga teknis (Undang-Undang No 20 tahun 2003). Tenaga struktural akan menempati jabatan-jabatan pimpinan yang bertanggung jawab baik langsung maupun tidak langsung terhadap satuan pendidikan, seperti menteri pendidikan, kepala kantor wilayah, wakil kepala sekolah urusan kurikulum, dan lainnya. Jabatan berikutnya adalah tenaga fungsional yang mengandalkan keahlian akademis kependidikan, seperti pengembang alat tes, peneliti, tenaga pustakawan, fasilitator, dan pekerja lainnya. Tenaga teknis kependidikan merupakan tenaga kependidikan yang dituntut cakap dalam teknik operasional atau teknik administratif dalam bekerja, seperti petugas tata usaha, pelatih, teknisi sumber belajar, dan tenaga lainnya.

Peran sebagai dosen dan tenaga kependidikan merupakan tugas yang mulia karena memiliki tujuan untuk membangun generasi muda bangsa yang lebih bermanfaat, sehingga sudah seharusnya dosen dan tenaga kependidikan memperoleh hak yang seimbang dengan kewajiban atau tugasnya. Hak dan kewajiban bagi dosen telah diatur dalam Undang-Undang Nomor 12 tahun 2012, sedangkan bagi tenaga kependidikan, hak serta kewajibannya diatur dalam Undang-Undang Nomor 20 tahun 2003. Hak ini juga menjamin kesejahteraan bagi dosen dan tenaga kependidikan baik secara materi maupun non materi, sebagai penghargaan atas jasa para dosen dan tenaga kependidikan. Kesejahtaeraan yang dimaksud seperti perasaan aman, kebebasan dalam berbagai hal, kesempatan untuk meningkatkan kemampuan sesuai bidangnya, dan sebagainya. 
Kesejahteraan atau yang dalam Bahasa Inggris disebut dengan well-being terbagi menjadi 2 bentuk, yaitu objective well-being (OWB) dan subjective well-being (SWB). OWB merupakan sebuah kepuasan yang berhubungan dengan kebutuhan dasar, bersifat universal dan berlaku untuk mayoritas masyarakat, sedangkan SWB adalah kepuasan hidup secara keseluruhan yang akan memiliki penilaian berbeda pada masing-masing individu (Diener, 2009). Jika pengukuran terhadap OWB berdasar pada nilai-nilai universal seperti kepercayaan, keyakinan, dan nilai-nilai yang ditanamkan di masyarakat, penilaian terhadap SWB akan lebih fokus pada persepsi dan perasaan individual. Penilitian ini akan lebih berfokus pada SWB agar pembahasannya tidak terlalu meluas dan dapat spesifik pada beberapa domain yang mengukur kepuasan hidup secara subjektif.

Menurut Diener (2009), definisi SWB dapat dibedakan dalam tiga kategori. Pertama, SWB adalah beberapa keinginan berkualitas yang diharapkan dapat dimiliki setiap orang. Kedua, SWB merupakan sebuah penilaian menyeluruh terhadap berbagai macam kriteria dalam kehidupan individu. Pengertian SWB juga dibedakan ketika digunakan dalam percakapan sehari-hari, yaitu saat perasaan positif lebih besar daripada perasaan negatif. Berdasarkan beberapa definisi di atas, dapat disimpulkan bahwa SWB merupakan penilaian positif individual terhadap pengalaman hidup. Penilaian tersebut terdiri dari penilaian kognitif dan afektif, dan diperlihatkan dengan adanya kesejahteraan psikologis.

SWB terdiri dalam tiga komponen umum (Diener dalam Suh dan Oishi, 2002), yaitu (a) kepuasan hidup, yang merupakan penilaian reflektif individu terkait bagaimana kebaikan terjadi terhadap dirinya. Individu yang mampu menerima diri serta lingkungan secara positif, akan merasa puas terhadap hidupnya (Hurlock, 1980); (b) afeksi positif, yang ditandai dengan pengalaman emosi serta mood menyenangkan (Diener, 2005); serta (c) afeksi negatif, yaitu suasana hati dan mood tidak menyenangkan, atau merefleksikan respon negatif yang dialami individu (Diener, 2005). Berdasarkan tiga komponen yang diatas, maka dapat disimpulkan bahwa jika memiliki kepuasan hidup, memiliki afek positif yang tinggi, serta memiliki sedikit afek negatif, maka individu akan merasa sejahtera dan bahagia dalam hidupnya.

Terdapat 11 dimensi yang mampu mengungkap tingkat SWB individu berdasarkan Nagpal dan Sell (1992), yaitu: general well-being-positive affective; family group support; expectation-achievement congruence; confidence in coping; social support; primary group concern; transcendence; perceived ill-health; deficiency in social contacts; inadequate mental mastery; dan general well-being-negative affect. Kesebelas dimensi ini juga akan diungkap 
melalui menggunakan sebuah kuesioner yang terlah terstandarisasi, sehingga ditemukan tingkat SWB dosen dan tenaga kependidikan secara keseluruhan.

Beberapa penelitian telah dilakukan lembaga-lembaga untuk mengungkap kepuasan hidup para dosen dan tenaga pendidik lainnya, salah satunya adalah penelitian yang diadakan oleh Jobplanet pada tahun 2016. Kepuasan hidup tersebut dianalisis atas beberapa faktor, diantaranya jenjang karir; gaji dan tunjangan; budaya perusahaan; work-life balance; serta faktor manajemen perusahaan. Berdasarkan penelitian tersebut, diketahui bahwa tingkat kepuasan tenaga pendidik masih rendah, yaitu di angka 2,91 (skala 5) pada jenjang karir; 2,79 (skala 5) pada gaji dan tunjangan; 3,07 (skala 5) pada work-life balance; 3,27 (skala 5) terhadap budaya perusahaan; dan sebesar 2,89 (skala 5) pada faktor manajemen perusahaan. Di sebuah artikel yang dimuat dalam rubrik Kompasiana, 31 Januari 2016, seorang tenaga kependidikan di sebuah perguruan tinggi swasta menyatakan bahwa kesejahteraan dosen dan tenaga kependidikan masih kurang diperhatikan, seperti kurang layaknya penghasilan bulanan yang diperoleh, karena pihak yayasan yang hanya mementingkan pemasukan dari kontribusi mahasiswa.

Para dosen dan guru di daerah Tenggarong, Kalimantan Timur juga melaporkan kurang diperhatikannya kesejahteraan profesi ini oleh pihak yang berwenang, sehingga memengaruhi kualitas, bahkan beberapa dosen dan guru harus melakukan pekerjaan sampingan untuk memenuhi kebutuhan hidup mereka. Fenomena-fenomena tersebut yang melatarbelakangi ketertarikan peneliti untuk mencari tahu mengenai bagaimana tingkat SWB dosen dan tenaga kependidikan yang mengabdi di fakultas P dan EB, universitas A. Setelah diketahui tingkat SWB, peneliti juga akan mengajukan rancangan intervensi psikologi untuk meningkatkan tingkat SWB di kedua fakultas tersebut, sehingga para dosen dan tenaga kependidikan dapat merasa semakin dihargai, yang dapat memengaruhi kinerja nantinya.

\section{Metode}

Penelitian ini menggunakan pendekatan kuantitatif. Berdasarkan pendapat Donmoyer (dalam Given, 2008) pendekatan kuantitatif merupakan kajian empiris yang bertujuan untuk mengumpulkan, menganalisa, dan menampilkan data dalam bentuk numerik. Jenis penelitian ini merupakan penelitian survei deskriptif. Penelitian survei bertujuan untuk memberikan gambaran lebih detail tentang gejala atau fenomena, dengan menggunakan kuesioner sebagai instrumen penelitian dan kondisi penelitian tidak dimanipulasi oleh peneliti (Saputra, 2003). 
Populasi dalam penelitian ini adalah pegawai dan dosen di fakultas P dan fakultas EB di universitas A. Selanjutnya pemilihan subjek dilakukan dengan menggunakan teknik sampling insidental, yakni subjek merupakan individu yang bertemu peneliti secara kebetulan dan dianggap layak sebagai sumber data (Sugiyono, 2016). Peneliti akan meminta bantuan para dosen dan tenaga kependidikan yang memenuhi persyaratan untuk menjadi responden dalam penelitian ini, dengan mengisi kuesioner. Kriteria subjek penelitian adalah dosen dan tenaga kependidikan di fakultas EB dan P, dengan mengabaikan lama bekerja, jenis kelamin, maupun status pekerjaan, namun faktor-faktor yang diabaikan tersebut akan dijadikan data deskriptif atas responden penelitian.

Skala pengukuran dalam penelitian ini menggunakan skala SWB yang diadaptasi dari Subjective well-being inventory (SUBI) (Nagpal \& Sell, 1992), dengan jenis data interval, dan disajikan dalam bentuk pernyataan. Instrumen ini bertujuan untuk mengukur perasaan wellbeing atau ill-being individu dalam menghadapi kejadian sehari-hari. Berikut adalah penjelasan dari masing-masing dimensi yang terdapat dalam SUBI:

1. General well-being-positive affective, yang mefleksikan perasaan well-being saat keseluruhan hidup dipersepsikan berjalan lancar dan tanpa gangguan. Dinyatakan juga bahwa beberapa faktor spesifik seperti kehidupan keluarga atau pekerjaan tidak memberikan sumbangsih besar terhadap faktor umum ini.

2. Expectation-achievement congruence. Faktor ini menjelaskan bahwa secara umum wellbeing diperoleh dengan meraih kesuksesan dan standar hidup yang sesuai dengan harapan, atau yang disebut juga dengan kepuasan.

3. Confidence in coping. Faktor tersebut berhubungan dengan kekuatan personal dan kemampuan mengatasi situasi krisis atau yang tidak diinginkan. Dapat juga dikatakan sebagai kesehatan mental yang positif dalam konteks ekologis (kemampuan beradaptasi terhadap perubahan dan menghadapi keragaman tanpa gangguan).

4. Transcendence merupakan faktor yang berhubungan dengan pengalaman hidup diluar rasionalitas dan kebiasaan sehari-hari, bahwa well-being juga berasal dari penilaian kualitas spiritual.

5. Family group support merupakan faktor yang mefleksikan tentang perasaan positif yang muncul dari adanya persepsi bahwa keluarga besar (diluar pasangan dan anak), sebagai anggota yang saling suportif, berhubungan timbal balik, serta dekat secara emosional.

6. Social support. Faktor ini mengandung aitem yang mendeskripsikan mengenai keberadaan lingkungan sosial di luar keluarga, sebagai pendukung kehidupan seharihari dan dalam situasi krisis. 
7. Primary group concern. Dalam faktor ini, aitem positif dan negatif saling berhubungan dan membentuk sebuah kluster. Kluster ini memiliki korelasi yang tinggi dengan aitem "pendapatan pasangan", yang menjelaskan bahwa kehidupan keluarga dianggap lebih bahagia jika pasangan ini bekerja.

8. Inadequate mental mastery. Aitem dalam faktor ini menunjukkan kurangnya kontrol, atau ketidakmampuan dalam mengatasi beberapa aspek kehidupan sehari-hari secara efektif, baik dari dalam diri maupun dari lingkungan, yang dapat mengurangi well-being individu.

9. Perceived ill-health. Aitem-aitem dalam faktor ini mengandung keluhan yang dirasakan individu, namun tidak disamakan dengan somatisasi.

10. Deficiency in social contacts. Faktor ini secara umum membahas tentang perasaan khawatir karena tidak disukai dan perasaan merindukan rekan-rekan, yang merupakan aitem negatif dari konstruk jaringan sosial.

11. General well-being-negative affect. Aitem-aitem pada faktor ini merefleksikan tentang pandangan umum dan keseluruhan yang depresif/menekan terhadap hidup.

Aitem-aitem dalam skala pengukuran tersebut bertujuan untuk melihat kontribusi faktor pembentuk SWB terhadap tingkat SWB individu. Sekor keseluruhan akan menunjukkan tingkat SWB individu secara umum. Sekor akan bergerak dari nilai 1 sampai 5. Sekor yang berlaku untuk aitem favorable 5 =sangat sesuai; 4=sesuai; 3 =cukup sesuai; 2 =tidak sesuai; $1=$ sangat tidak sesuai. Untuk aitem non favorable $5=$ sangat tidak sesuai; $4=$ tidak sesuai; $3=$ cukup sesuai; $2=$ sesuai; $1=$ sangat sesuai. Semakin tinggi sekor menunjukkan bahwa tingkat SWB yang dimiliki semakin tinggi, dan sebaliknya.

\section{Hasil}

Pengambilan data penelitian dilaksanakan di fakultas EB dan fakultas P Universitas A. Kuesioner yang merupakan alat pengambilan data dibagikan kepada responden, yaitu dosen dan pegawai, dengan jumlah 74 orang responden. Pengambilan data di fakultas EB dan P dilakukan dari minggu pertama hingga akhir bulan November 2019.

a. Jenis Kelamin

Tabel 1

Gambaran Responden Berdasarkan Jenis Kelamin

\begin{tabular}{lll}
\hline Jenis kelamin & Frekuensi & Persentase \\
\hline
\end{tabular}




\begin{tabular}{lcc}
\hline Laki-laki & 42 & $56,76 \%$ \\
Perempuan & 32 & $43,24 \%$ \\
\hline Total & 74 & $100 \%$ \\
\hline
\end{tabular}

Dari tabel di atas dapat diketahui bahwa responden yang terlibat dalam penelitian ini adalah laki-laki sebanyak 42 responden (56,76\%) dari keseluruhan sampel, sedangkan responden perempuan berjumlah 32 responden $(43,24 \%)$ dari keseluruhan sampel.

b. Tingkat Pendidikan

Tabel 2

Gambaran Responden Berdasarkan Tingkat Pendidikan

\begin{tabular}{lcc}
\hline Tingkat Pendidikan & Frekuensi & Persentase \\
\hline SD & 3 & $4,05 \%$ \\
\hline SMP & 1 & $1,35 \%$ \\
\hline SMA & 29 & $39,19 \%$ \\
\hline Diploma & 2 & $2,7 \%$ \\
\hline S1 & 27 & $36,49 \%$ \\
\hline S2 & 4 & $5,4 \%$ \\
\hline S3 & 1 & $1,35 \%$ \\
\hline Tidak mengisi & 7 & $9,46 \%$ \\
\hline Total & 74 & $100 \%$ \\
\hline
\end{tabular}

Responden dalam penelitian ini adalah dosen dan tenaga kependidikan dengan latar belakang pendidikan terbanyak adalah SMA, yaitu 39,19\%, dan yang paling sedikit dengan latar belakang SMP sebanyak 1,35\% yang bekerja sebagai tenaga kependidikan, serta 1,35\% lain memiliki latar belakang pendidikan doktoral, yang merupakan seorang dosen.

c. Status Pernikahan

Tabel 3

Gambaran Responden Berdasarkan Status Pernikahan

\begin{tabular}{lll}
\hline Status Pernikahan & Frekuensi & Persentase \\
\hline
\end{tabular}


WACANA

\begin{tabular}{lcc}
\hline Belum menikah & 10 & $13,51 \%$ \\
Sudah menikah & 59 & $79,73 \%$ \\
Tidak mengisi & 5 & $6,76 \%$ \\
\hline Total & 74 & $100 \%$ \\
\hline
\end{tabular}

Sebagian besar responden dalam penelitian sudah menikah, yaitu 59 orang (79,73\%), sedangkan yang belum menikah sebanyak 10 orang responden $(13,51 \%)$.

d. Status Kepegawaian

Tabel 4

Gambaran Responden Berdasarkan Status Kepegawaian

\begin{tabular}{lcc}
\hline Status Kepegawaian & Frekuensi & Persentase \\
\hline Tetap & 54 & $72,97 \%$ \\
Tidak tetap & 17 & $22,97 \%$ \\
Tidak mengisi & 3 & $4,06 \%$ \\
\hline Total & 112 & $100 \%$ \\
\hline
\end{tabular}

Responden dalam penelitian ini sebagian besar merupakan dosen dan tenaga kependidikan yang berstatus pegawai tetap, dengan jumlah sebanyak 54 orang (72,97\%) dari keseluruhan sampel, sedangkan sebanyak 17 orang responden $(22,97 \%)$ berstatus pegawai tidak tetap.

e. Hasil uji normalitas

Tabel 5

Hasil Uji Normalitas Variabel Subjective Well-Being \& Dimensi Subjective Well-Being

\begin{tabular}{ccc}
\hline Variabel/Dimensi & $\mathbf{( p )}$ & Keterangan \\
\hline Subjective Well-Being & 0,526 & Distribusi Normal \\
General well-being-positive affective & 0,853 & Distribusi Normal \\
Expectation-achievement congruence & 0,477 & Distribusi Normal \\
Confidence in coping & 0,726 & Distribusi Normal \\
Transcendence & 0,528 & Distribusi Normal \\
Family group support & 0,526 & Distribusi Normal \\
Social support & 0,195 & Distribusi Normal
\end{tabular}




$\begin{array}{ccc}\text { Primary group concern } & 0,126 & \text { Distribusi Normal } \\ \text { Inadequate mental mastery } & 0,434 & \text { Distribusi Normal } \\ \text { Perceived ill-health } & 0,863 & \text { Distribusi Normal } \\ \text { Deficiency in social contacts } & 0,436 & \text { Distribusi Normal } \\ \text { General well-being-negative affect } & 0,158 & \text { Distribusi Normal }\end{array}$

Berdasarkan hasil uji normalitas, diketahui bahwa sebaran data pada variabel SWB memiliki nilai signifikansi (p) 0,526, atau mempunyai probalilitas di atas 0,05 ( $p>0,05)$. Hal ini berarti sebaran data pada variabel SWB memiliki distribusi normal dan memenuhi syarat untuk melakukan analisa data melalui analisis parametrik. Sebaran data dari kesebelas dimensi yang menjadi pembentuk variabel SWB memiliki nilai probabilitas di atas 0,05 ( $p>0,05)$. Hal tersebut menunjukkan bahwa sebaran data pada masing-masing dimensi dalam variabel SWB memiliki distribusi normal dan memenuhi syarat untuk melakukan analisa data melalui analisis parametrik.

f. Kategorisasi dan interpretasi sekor

Tabel 6

Kategorisasi dan Interpretasi sekor Subjective Well-Being

\begin{tabular}{|c|c|c|c|c|}
\hline Rumus & Norma & Frekuensi & $\begin{array}{l}\text { Persentase } \\
\text { (\%) }\end{array}$ & Kategori \\
\hline$X \leq(\mu-1,5 \sigma)$ & $X \leq 80$ & - & - & Sangat rendah \\
\hline $\begin{array}{l}(\mu-1,5 \sigma)<X \leq(\mu-0,5 \sigma \\
)\end{array}$ & $80<X \leq 106,67$ & 1 & $1,35 \%$ & Rendah \\
\hline $\begin{array}{l}(\mu-0,5 \sigma)<X \leq(\mu+0,5 \sigma \\
)\end{array}$ & $106,67<X \leq 133,33$ & 20 & $27,03 \%$ & Sedang \\
\hline $\begin{array}{l}(\mu+0,5 \sigma)<X \leq(\mu+1,5 \\
\sigma)\end{array}$ & $133,33<X \leq 160$ & 40 & $54,05 \%$ & Tinggi \\
\hline$(\mu+1,5 \sigma)<X$ & $160<X$ & 13 & $17,57 \%$ & Sangat tinggi \\
\hline Total & & 74 & $100 \%$ & \\
\hline
\end{tabular}

Berdasarkan tabel diatas dapat dilihat bahwa sebagian besar responden, yaitu 40 orang $(54,05 \%)$, memiliki tingkat SWB yang tinggi. Sebanyak 20 responden $(27,03 \%)$ berada di tingkatan sedang, 13 responden atau 17,57\% memiliki tingkat SWB yang sangat tinggi, dan 1,35\% atau sebanyak 1 responden sisanya memiliki tingkat SWB yang rendah. Sehingga dapat dikatakan bahwa sebagian besar responden yang terdiri dari dosen dan tenaga kependidikan ini memiliki pandangan positif terhadap hidup yang mencerminkan kesejahteraan psikologis secara keseluruhan. 


\section{Diskusi}

Menelaah hasil penelitian, terlihat bahwa lebih dari setengah $(71,62 \%)$ presentase responden yang mengisi kuesioner SWB menilai bahwa kehidupan mereka telah berjalan positif, baik dinilai secara fisik maupun mental, dalam hal ini dinyatakan dengan tingkat SWB yang tinggi. Sebanyak 20 responden $(27,03 \%)$ berada di tingkatan sedang, dan hanya 1,35\% atau sebanyak 1 responden sisanya memiliki tingkat SWB yang rendah. Sesuai dengan konsep yang dinyatakan Nagpal dan Sell (1992), SWB merupakan sebuah kesatuan pengukuran dan setelah dianalisis akan mampu memprediksi tingkat SWB individu secara keseluruhan. Terdapat 11 dimensi yang dianggap mampu mengukur tingkat SWB individu, yaitu general wellbeing-positive affective; family group support; expectation-achievement congruence; confidence in coping; social support; primary group concern; transcendence; perceived ill-health; deficiency in social contacts; inadequate mental mastery; dan general well-being-negative affect. Semakin tinggi sekor yang diperoleh pada keseluruhan dimensi, maka semakin tinggi SWB yang dirasakan individu dalam hidupnya.

Peneliti telah melakukan analisis terhadap masing-masing dimensi hingga ditemukan beberapa dimensi, dimana jawaban responden berada pada kategori rendah bahkan sangat rendah, yang menunjukkan bahwa dimensi tersebut memiliki pengaruh terhadap rendahnya tingkat SWB individu. Adapun dimensi yang paling banyak dijawab pada kategori rendah adalah dimensi deficiency in social contacts. Dimensi ini berkaitan dengan kekhawatiran akan kehilangan teman, merindukan kawan lama, dan khawatir bahwa dirinya tidak disukai. Sebanyak 47,3\% responden menjawab pada kategori tinggi bahkan sangat tinggi di aitem-aitem yang menyusun instrumen ini. Kehidupan sosial merupakan suatu isu yang sangat penting dalam kehidupan manusia (Seel, 2012). Manusia merupakan mahluk yang memiliki kodrat sebagai mahluk sosial, yang membutuhkan interaksi sosial bersama manusia lain dalam membangun kehidupannya. Namun dimensi ini tidak dapat digunakan sebagai prediktor, karena ditemukan bahwa aitem-aitem pembentuk dimensi ini memiliki derajat validitas yang kurang dari 0,25, yang berarti bahwa ketiga aitem tersebut tidak mampu menunjukkan kemampuannya sebagai alat ukur terhadap dimensi deficiency in social contacts pada penelitian ini.

Dimensi berikutnya yang memberikan pengaruh terhadap rendahnya tingkat SWB individu adalah perceived ill-health. Dimensi ini berhubungan dengan keluhan-keluhan fisik yang dialami oleh individu, seperti sakit pada beberapa bagian tubuh, jantung berdebar 
kencang, sering merasa pening, mudah lelah, tidur terganggu, dan kekhawatiran akan kesehatan, namun keluhan-keluhan ini dibedakan dengan somatisasi. Terdapat 6 aitem unfavorable sebagai pernyataan yang mewakili dimensi ini. Dari 74 responden, sejumlah 54 orang $(72,97 \%)$ berada pada kategori tinggi dan sangat tinggi. Hal ini menunjukkan bahwa banyak responden yang sering mengeluhkan sakit fisik dan hal tersebut dapat memengaruhi SWB yang dirasakan responden secara keseluruhan.

Dalam penugasan sehari-hari, lingkup kerja responden yang merupakan dosen dan tenaga kependidikan sangat berbeda. Jika dosen akan lebih banyak berhadapan dengan mahasiswa terkait dengan materi pembelajaran, maka tenaga kependidikan akan lebih banyak berhadapan dengan mahasiswa sehubungan hal administrasi. Banyak potensi konflik yang dapat terjadi pada responden, sesuai dengan umumnya dalam dunia kerja. Seperti adanya konflik dengan mahasiswa atau rekan sejawat, suasana kerja yang kurang kondusif, tidak jelasnya regulasi, bahkan karena imbalan yang dianggap belum sepadan. Dalam menghadapi konflik seperti ini, diperlukan kapasitas mental yang baik untuk menyeimbangkan keadaan, dan seperti yang kita ketahui bahwa aktivitas mental sangat berpengaruh pada kondisi fisik individu, terlebih saat menghadapi situasi yang tidak diharapkan dan individu kurang memiliki kecakapan untuk mengatas situasi tersebut.

Hampir setiap pekerjaan diikuti dengan resiko kelelahan (fatigue). Kelelahan dapat dikategorikan sebagai penyakit yang terjadi akibat akumulasi kelelahan kerja (Ichie, Oshawa, \& Sato, 2004). Kelelahan kerja dapat terjadi karena rendahnya kualitas dan kuantitas tidur individu; adanya keadaan yang menuntut bekerja pada waktu yang seharusnya digunakan untuk tidur; atau adanya aktivitas mental dan fisik yang tidak sesuai dengan tempat kerja (Setyawati, 2010). Mengantuk adalah salah satu gejala kelelahan yang sering terjadi saat aktivitas akademik, yang menunjukkan bahwa tubuh perlu beristirahat. Buruknya kuantitas dan kualitas tidur merupakan alasan umum dosen mengantuk (Yogisutanti, 2014). Waktu tidur yang kurang dapat terjadi saat dosen mengerjakan tugas untuk mempersiapkan bahan ajar, atau adanya tugas lain di rumah pada waktu yang seharusnya digunakan untuk tidur. Beban pekerjaan yang dilanjutkan di rumah, akan mengurangi kuantitas jam istirahat dosen, dan dapat berdampak pada penurunan kesehatan. Hasil penelitian juga ini sejalan dengan penelitian oleh Yasumasa, Takeshi, dan Ippei (2008), yang mengungkapkan bahwa lama waktu kerja berhubungan dengan kelelahan dan tingkat konsentrasi pekerja. 
Kelelahan kerja yang berpengaruh terhadap kesehatan ini tidak hanya dialami oleh dosen sebagai tenaga pendidik, namun juga dialami oleh tenaga kependidikan sebagai pelaksana teknis yang mendukung kelancaran proses belajar mengajar di sebuah universitas. Pengurusan kartu rencana studi, kartu hasil studi, presensi mahasiswa, serta banyaknya urusan administrasi lainnya, berbanding lurus dengan banyaknya mahasiswa yang memiliki urusanurusan administrasi tersebut, akan memengaruhi kesehatan fisik dan mental para tenaga kependidikan (Roshadi, 2014). Jika dilihat dari data demografis tenaga kependidikan di kedua fakultas, terlihat bahwa sebagian besar respoden berusia di atas 30 tahun dan sudah menikah. Hal ini didukung dengan beberapa penelitian yang menyatakan bahwa usia pekerja berpengaruh terhadap kelelahan kerja, terkait dengan kemampuan motorik dan pengelihatan yang dimiliki (Chesnal, Rattu \& Lampus, 2015). Namun, faktor spesifik yang memengaruhi terbentuknya perceived ill-health di universitas A perlu diteliti lebih lanjut terkait dengan belum adanya bukti empiris atas hal tersebut.

\section{Implikasi}

Dimensi perceived ill-health merupakan dimensi yang paling berkontribusi dalam rendahnya tingkat SWB yang diraih responden. Dimensi ini terkait dengan keluhan-keluhan fisik yang dialami oleh individu, seperti sakit pada beberapa bagian tubuh, jantung berdebar kencang, sering merasa pening, mudah lelah, tidur terganggu, dan khawatir akan kesehatan. Berdasarkan hasil penelitian tersebut, institusi terkait diharapkan dapat mempertimbangkan langkah preventif, kuratif, dan promotif dalam meningkatkan SWB para dosen dan tenaga kependidikan di Universitas A.

Adapun saran bagi penelitian selanjutnya adalah agar dapat menggunakan responden sebanyak mungkin, agar hasil penelitian dapat digeneralisasikan bagi seluruh populasi. Peneliti juga diharapkan lebih memperhatikan teknis pengisian kuesioner, terlebih pada bagian identitas, sehingga pengisiannya lengkap, karena hasil penelitian yang lebih detail akan dapat diungkap. Penelitian selanjutnya juga diharapkan meneliti lebih detail mengenai faktor dalam dimensi perceived ill-health yang mempengaruhi tingkat SWB.

\section{Daftar Pustaka}

Azwar, S. (2010). Metode Penelitian. Yogyakarta: Pustaka Belajar.

Azwar, S. (2010). Reliabilitas dan Validitas edisi ke 3. Yogyakarta : Pustaka Pelajar.

Borman, W. C., Hgen, D. R., \& Klimoski, R. J. (2003). Handbook of Psychology Volume 12 Industrial and Organizational Psychology. United State of America: John Wiley \& Sons.

Melati, S. (2013). "Hubungan antara umur, masa kerja dan status gizi dengan kelelahan kerja pada pekerja mebel di Cv. Mercusuar dan Cv. Mariska Desa Leilem Kecamatan Sonder Kabupaten Minahasa. Skripsi. Universitas Sam Ratulangi Manado. (Online) http://fkm.unsrat.ac.id/ 
Diener, E. \& Chan, M.Y. (2011). Happy People Live Longer: Subjective Well-Being Contributes to Health and Longevity, Applied Psychology: Health and Well-Being, 3(1), pp. 1-43 .

Haryono, W., Suryani, D \& Wulandari, Y. (2009). Hubungan antara beban kerja, stres kerja Dan tingkat konflik dengan kelelahan kerja Perawat di rumah sakit islam yogyakarta pdhi Kota Yogyakarta. Jurnal Kes Mas Uad Vol.3 No.3 ISSN : 1978-0575, 162-232.

Hurrell, J.J. (2005). Organizational stress interventions. In J.Barling, E. K. Kelloway, \& M. R. Frone (Eds.), Handbook of work stress (pp. 623-645). Thousand Oaks, California: Sage.

Naswall, K., Hellgren, J. \& Sverke, M. (2008). The Individual in the Changing Working Life. United States of America; Cambridge University Press.

Republik Indonesia. (2005). Undang-Undang Republik Indonesia nomor 14 tahun 2005 tentang Guru dan Dosen. Presiden Republik Indonesia. Jakarta.

Republik Indonesia. (2012). Undang-Undang Republik Indonesia nomor 12 tahun 2012 tentang Pendidikan Tinggi. Presiden Republik Indonesia. Jakarta.

Republik Indonesia. (2016). Peraturan Presiden Republik Indonesia Nomor 10 Tahun 2016 tentang Dosen dan Tenaga Kependidikan pada Perguruan Tinggi Negeri Baru. Presiden Republik Indonesia. Jakarta.

Roshadi, I. (2014). "Hubungan antara kelelahan kerja dengan produktivitas kerja karyawan di fakultas dakwah dan komunikasi UIN Sunan Kalijaga Yogyakarta." Yogyakarta.

Seel, N.M. (Ed). 2012. Social Interaction, Encyclopedia of the Sciences of Learning. New York: Springer.

Sell, H. \& Nagpal, R. 1992. Assessment of subjective well-being. The subjective well-being inventory (SUBI). India: World Health Organization. 